\title{
The Topic of Jihad in Islamic Education and its Implications in Students' Character Building
}

\author{
Yulia Rahman', A. Rahman Ritonga ${ }^{2}$ \\ ${ }^{1}$ Department of Islamic Education, Institut Agama Islam Negeri (IAIN) Bukittinggi, \\ ${ }^{2}$ Bukittinggi, Indonesia, Department of Ulumul Hadits, Institut Agama Islam Negeri (IAIN) Bukittinggi, \\ Bukittinggi, Indonesia \\ *yuliarahman@iainbukittinggi.ac.id
}

\begin{abstract}
The subject matter in the Islamic education system refers to comprehensive Islamic teachings and its sources, Al-Qur'an and Hadith. The topic of jihad is an important part of Islamic teachings that cannot be separated from other topics, such as aqidah (faith), syari'ah (law), ibadah (worship), morals and muamalah (interactions). The discourse of eliminating the topic of jihad from the Islamic education curriculum raises controversy among education observers, considering that the subject had actually sparked the spirit for independence and did not indicate rejection of the sense of nationalism of the Muslims. The aim of this paper is to analyze the learning concept of the topic of jihad in Islamic educational institutions and to see its implications towards the character building of students. The method used is literature review which relies on information and data from various books, journals, articles and documents. This paper concludes that learning the topic of jihad in Islamic education is able to foster a brave and emphatic attitude in defending the honor of religion and country, perseverance in achieving success in the world and the hereafter, as well as inspire the spirit of nationalism and unity. All these characters are built on the basis of strong tauhid (monotheism) as the spirit of jihad grows on the foundation of faith in Allah. This conclusion refutes the opinion that learning the topic of jihad in Islamic boarding schools and madrasas is the cause of the growth of radicalism and terrorism.
\end{abstract}

Keywords: jihad; Islamic education; character building

\section{Introduction}

Islamic education in Indonesia always faces various challenges from time to time. In the last few decades, Islamic Education has struggled to defend itself against accusations of radicalism and exclusivity. Hefner stated that since the Bali Bombing incident, Islamic education in Southeast Asia, especially Indonesia, has become the world's spotlight [1]. The Journal of Asian Affair accuses an even more explicit statement of equating Islamic boarding schools and traditional madrasas in Indonesia with madrasas in Pakistan. The independent status of traditional Islamic boarding schools and madrasas from government control and authority has become an easy target for other parties to instill values of radicalism [2], [3]. This prejudice still persists until today along with the increasing number of partial understanding of Islamic teachings itself. 
One form of partial understanding that has impact on the emergence of mistakes in formulating learning materials is the revision of jihad topic that is considered no longer relevant to the process of building student character. The topic of jihad, which is narrowly understood as a history of war and conquest in the early days of Islam, is feared to internalize the character of violence and terrorism. The term jihvmiad is often identified with the words al-harb, al-qital and al-ghazwah, thus creating a negative image that Islam is propogated through war and violence [4]. This narrow understanding has an impact on the implementation of revisions to the Core Competencies and Basic Competencies of Islamic religious learning materials in madrasas that discuss jihad [5].

The aim of this study is to look at the development of material and learning methods on the topic of jihad in Islamic education and to find out the impact of the internalization of its values on the character building of students. Similar research has been discussed in several papers, such as a "The Implementation of Jihad Concept in Education" by Ali Imron in the Proceedings of the 6th International Conference on Community Development (ICCD 2019). This research concludes that the topic of jihad in education is applied on the basis of an understanding of faith in Allah, to practice self-discipline, to strive for learning and teaching, and to train students to socialize well within the school or outside [6]. A study titled "Pesantren Religious Paradigm: Aqeedah, Plurality, and Jihad" by Arifinsyah and friends concluded that the topic of jihad in Islamic boarding schools was understood wisely, not only as intellectual jihad and struggle for social interests in accordance with the main goal of the pesantren to bring in a muslim generation which is beneficial to society [7].

\section{Methodology}

This paper is a qualitative research using library research methods. Qualitative research is a study in which data is expressed in verbal form instead of numbers and its analysis does not use statistical techniques [8]. The library research method is a series of activities related to the method of collecting library data, reading and taking notes and processing research materials [9]. This method makes qualitative research obtain adequate data sources and analysis. Literature review is carried out systematically to collect, manage and summarize data to find answers and solutions to problems. Through this method, the research is expected to bring about objective and comprehensive conclusions regarding the learning of the topic of jihad in the perspective of Islamic education and its impact on the character building of students in Islamic education institutions, especially Islamic boarding schools and madrasas.

\section{Result and Discussion}

1) The concept of Jihad in Islam

The term of jihad comes from Arabic with a general meaning. The word (ج)) as the root of jihad describeds the meaning of energy, strength and hard work [10]. In the context of Islamic teachings, this word contains a meaning that includes all form of ibadah (worshipping) physical and non physical, striving to achieve goals through physical, emotional, material, energy, and scientific struggles [11]. In its current development, the word jihad tends to be understood as a struggle to fight enemies to defend the glory of religion [12]. This has an impact on the emergence of misunderstandings and a negative impression that 
Islam is propagated through violence. Even non-Muslims equate jihad with the term holy war, a Christian tradition of war with the aim of Christianizing people of other religions [11]. Whereas in the Islamic tradition, jihad aims to preach Islam without coercion to embrace it. Even in practice, the conquests still gave non-Muslims permission to carry out their respective religious rituals and traditions. Therefore, it becomes very important to restore the meaning of jihad based on to the Al-Quran and Hadith, so that the conclusions obtained are comprehensive with clear and emphatic meanings.

The word jihad in the verses of the Al-Qur'an was revealed in two contexts of period: The Mecca and the Medina period. During the Mecca period, verses concerning jihad were revealed 8 times; 4 verses relating to the teachings of jihad and 4 others talk about other contexts [13]. The verses about jihad in this period generally refer to the motivation to be patient when facing the cruelty and intimidation of the Quraish (unbeliever), and to continue to persistently carry out the preaching of Islam, verbally and exemplary [14]. In Surah alFurqan verse 52, Allah says: "So do not follow the unbelievers, and do jihad against them with the Qur'an with great jihad". The word jihad in this verse means jihad bi al-hujjah, seriously preaching Islam with the Quran, spreading its teachings and arguing to prove its truth [15]. The word jihad is also found in surah al-Nahl verse 110: "And truly your Lord (protector) is for those who emigrate after suffering a trial, then they do jihad and be patient; verily your Lord after that is truly Forgiving, Most Merciful". The word jihad here means persistence in the process of hijrah (migrating), struggling and being patient in defending Islam despite the attacks of the musyriks (polytheists). Another meaning of jihad is seriousness and sincerity against lust [16], as Allah says in surah al-'Ankabut verse 69: "And those who do jihad to (seek our pleasure), We will really show them Our ways, and verily Allah is with those who do good".

Meanwhile, in the Medina period, the verse about jihad came down 33 times, where the Muslims were getting stronger spiritually, socio-politically and military [17]. The meaning of jihad in this period is related to the number of wars faced by Muslims, whether to defend themselves from enemy attacks, to defend the glory of Islam or to spread Islamic preaching to other areas through conquests. Jihad in the context of war in Madani verses uses several different terms, namely; al-qital fi sabil Allah, al-harb, al-ghazwu and al-nafr which contain the meaning of war physically and materially [18]. Afzalur Rahman states that war orders are for self-preservation and self defense [19]. More than that, Jihad is not only a matter of ideology and belief, but also protecting life, house and property [20] which is owned by everyone who is under the rule of Islamic government, both Muslim and non-Muslim.

Based on the development of the meaning of jihad above, it is obvious that jihad is a fundamental part of Islam. The important value in the concept of jihad can give a significant impact on building Muslim character. The meaning of jihad in Mecca period is build Muslim character to be firm, patient and persistent life. The stage of jihad training in this context needs to be carried out in the early days as a basic character to face future challenges and not to deviate from the boundaries of Islamic sharia. Meanwhile, the meaning of jihad in the Medina period is the next stage of training to form a firm character, strong beliefs, discipline, to preach seriously, make sacrifices and is ready to defend religious honor physically and materially. This character-building exercise can be done in the next stage of education when a person's personality condition is mature intellectually, spiritually, emotionally, socially, economically and politically.

2) The Topic of Jihad in the Context of Islamic Education 
Islamic education is a system that aims to develop the potentials of students through learning and teaching based on Islamic teachings. Jihad, as one of the fundamental parts of Islamic teachings, is material that cannot be reduced from the Islamic education curriculum. This material is still taught to the younger generation of Muslims in the context of the meaning of jihad in general and specific (related to war). This has been going on for a long time at the Indigenous Archipelago educational institution: pesantren (boarding school). As educational and Islamic $d a^{\prime} w a h$ institutions, traditional pesantrens have contributed a lot for Indonesian independence through diplomatic or revolution. For example, the Jihad Resolution which was adopted by the ulama in the pesantren.

Jihad Resolution is considered a strategic decision that have great value in providing moral support to the country's leaders and igniting the patriotism of the santri (students), the people and the ulama in a physical revolution against the colonialists. The kyais (leaders of pesantrens) led the resistance to the death and gave command in front of the students. This is a real example that Islam teaches every Muslim to love the country with all its potential, including thoughts, time, wealth and life [21].

History proves that the jihad spirit of the kyai and santri in fighting colonialism is an implication of Jihad subject in traditional Islamic boarding schools. After independence, the material of jihad was still studied in the pesantren on an ongoing basis and there was absolutely no conflict with the spirit of nationalism. The Jihad Resolution is also considered a manifesto of the nationalism of the Indonesian kyai and ulama in achieving Indonesian independence. The resolution that came after the proclamation of independence became a milestone for Indonesian nationalism, which inspired the nation to fight for independence [21].

However, after the issues of terrorism were directed to Islamic boarding schools, the topic of jihad became one of the objects that is accused to be one factor of the growth of radicalism among kyai and santri resulting suicide bombings and terror attempts in the name of jihad against certain parties, such as religions, security and government. Along with this negative issue, education experts of pesantren are also aggressively defending themselves and proving that jihad-themed learning is not a factor in the growth of radicalism and terrorism values. So, there is no need to reduce or eliminate this topic from Islamic education curriculum. M. Quraish Shihab quotes Al-Raghib Al-Isfahani's opinion which concludes that jihad means exerting all energy to defeat three kinds of enemies: the real enemy, satan and the lusts within [10].

The study of jihad at the time of Prophet Muhammad proves that this theme has succeeded in shaping the noble character of the salaf al-shalih, the best generation of Muslims who have achieved success in various fields. Yusuf al-Qaradhawi revealed that the spirit of jihad had also shaped the character of the Prophet's companions in economic terms, namely they tried to seek sustenance and live [22]. This spirit also led Islamic civilization to reach its golden era, surpassing the glory of earlier civilizations such as Greece, Rome and Persia. The superior character of Muslims in all fields has made Muslims the best nation (khair al-ummah) throughout history [23].

In pesantren, jihad material is absorbed from classical books. Among the religious literature that is widely used is the Book of Fiqh which refers to the book of Fiqh al-Islami by Dr. Wahbah Zuhaili, Fathu al-Mu'in, and Fathu al-Qorib. The Tafsir book refers to the Tafsir Jalalain by Jalauddin al-Suyuthi and Jalaluddin al-Mahalli, also to the al-Qurtubi interpretation, the book of morals/tasawuf refers to the Ihya 'Ulum al-Dien book by Imam AlGhazali, and the Hadith book refers to the Bukhori Muslim [24]. Each of these classic books explains the topic of jihad in the perspective of each scientific field. 
In these literatures the topic of jihad is classified into three terms. First, mujahadah, namely spiritual warfare against lust. Second, ijtihad, which is to devote the ability to initiate laws through a strict method, and is projected to generate independent opinions in Islamic jurisprudence with the method of analogy (qiyas) based on the Qur'an and Hadith. Third; amar ma'ruf nahy munkar, the struggle to create a social environment that allows Muslims to implement sharia obligations, and adapt to their ethical norms. Fourth, qital fi sabil Allah, war to defend religion from something that threatens it with a code of ethics that has been described in the Quran and Hadith [24].

The four meanings of jihad above are included in the cognitive, affective and psychomotor education domains. Mujahada relies on spiritual and emotional abilities to control oneself to do good deeds and leave bad ones. The ability to perform mujahadah shows the development of students from an affective perspective related to attitudes, values, feelings, emotions and the degree of acceptance or rejection of an object. Through the material of jihad in the meaning of mujahada, students are required to be able to accept the problem, respond, take positive values, manage and make these values into characters [25].

Ijtihad relies on intellectual abilities to restate the concepts or principles that have been learned, with regard to thinking skills, competence to acquire knowledge, recognition, understanding, conceptualization, determination and reasoning (Bloom, 1956). Learning about ijtihad motivates students to be diligent in obtaining information to make decisions and find solutions to problems. Jihad in the sense of amar ma'ruf and nahi munkar relies on personal, social and professional potential which is the area of psychomotor education. The psychomotor domain includes competence to do work that involves limbs as well as competences related to physical movements consisting of reflex movements, basic movement skills, perceptual abilities, accuracy, complex skills, expressiveness and interpretation.

Meanwhile, jihad in the meaning of qital fi sabil Allah is an attitude that is taken with some shariah provisions, as a defensive and offensive action. War as a defensive action was only carried out after the revelation of the verse regarding permission to fight, Allah said; "It is permissible to fight for the people who are being fought, because in fact they have been persecuted. And verily Allah is truly Almighty to help them, (ie) people who have been expelled from their hometowns without a valid reason." (Q.S. alHajj/22:39-40). This verse was revealed after Muslims tried their best to be patient and restrained in facing the cruel torture that had claimed the lives of many Muslims. At that time, the companions (of Rasulullah) were eager to put up a fight to end this atrocity. However, the jihad was only permitted after moving to Medina. Even so, the war at this stage only acts as a defense measure when the Muslims are under attack from the others, not for attacking enemy territory [24].

As for war as an offensive action, Allah only ordered it after the hijrah, when the condition of the Muslims was strong in the religious, social, economic, political and military fields. Allah says: "It is obligatory for you to fight, even though fighting is something you hate. You may hate something even though it is good for you, and maybe you like something even though it is bad for you; Allah knows best, but you don't know." (QS. Al-Baqarah/2: 216). In addition, the order of war and conquest of territory as a way had strict rules. The legalization of jihad in the Quran is limited to several purposes, namely: First, fighting the musyrik (polytheists) who ignore the preaching of Islam and try to fight it with intimidation and various tortures in order to cancel the preaching. Second, fighting those who deprive Muslims of their rights. Third, fighting apostates, because they are considered to be endangering religion by carrying out acts of provocation and carrying out propaganda, as was done by Abu Bakr al-Sidiq as a preventive effort against religion. Fourth, fighting rebel groups (bhughats) 
who refuse to obey the lawful and right government, or violate laws and refuse to fulfill their obligations as citizens. Ali Bin Abi Thalib once waged a war like this as an effort to conserve the unity of Muslims [26]. As for the objectives of war that are negatively oriented, creating damage, robbing property, showing off strength and power, racism ('asabiyah), revenge, rivalry, or fighting over position, then the law is haram and cannot be categorized as jihad fi sabil Allah. Rasulullah SAW said: "Surely Allah does not accept deeds except those that are purely for His pleased." [27].

Thus, the meaning of jihad as a physical war does not deserve to be given the impression of violence in the spread of Islam, because it is necessary to look at the background and chronology of the course of the war. Then complemented with data on social, political, economic and cultural conditions during the war. This has greatly influenced the image of jihad as a learning material taught to the younger generation of Muslims.

The topic about jihad is an important part of the history of Islamic civilization. Eliminating this topic because of the negative impression that is accused is the same as inheriting a flawed Islamic history. The glory and virtue of the generation of sahabah as the golden generation, are not only due to their spiritual and intellectual excellence, but also enhanced by the brave, warrior and patriotic characters they get from the spirit of jihad and shahid fi sabil Allah. Under the ideological concept of of jihad, several Islamic leaders have delivered the Islamic caliphate to become one of the largest empires in the history of mankind which not only advanced in the military, but also in the control of civilization [28]. The role of jihad in achieving this should be an element of instilling character values for students with learning methods that support these goals. Collaboration of material design and appropriate jihad learning methods is able to restore the role of this material to form the positive character of students.

3) Implications of Learning the Topic of Jihad on Building Students Character.

The manifestation of jihad in Islam and its implementation throughout the history of the Islamic da'wah process is one important indicator of the positive influence of this topic on the character building of a Muslim. As previously mentioned, Jihad learning materials in Islamic boarding schools are integrated in various classical books on the theme of faith, fiqh, morals, tafsir and hadith. The integration of the jihad material in the various literatures has made learning this material more comprehensive and far from partial understanding. This affects the meaning and purpose of jihad, which actually in Islam is not to spread fear, violence, let alone terrorism. But it is precisely aimed at maintaining the dignity of religion, defending the honor of the nation and spreading Islamic $d a^{\prime} w h$ with the main aim of peace.

Jihad learning, both theoretically through the interpretation of the Quran and the explanation of the hadiths, as well as practically through researching the history of Islamic civilization, is able to create a positive picture of jihad as a medium for the formation of the noble characters of a Muslim.

The contribution of jihad education to character education can be seen through the relevance of jihad material to the pesantren education. First, spiritual and emotional development which includes characters of faith, taqwa, honesty, trustworthiness, fairness, responsibility, empathy, braveness, never gives up, willingness to sacrifice, and patriotic. Second, intellectual development, which includes intelligent, critical, creative, innovative and curious thinking, open-mind, productive, science-oriented, and reflective characters. Third, physical and kinesthetic development, which includes clean and healthy, disciplined, sportive, tough, reliable, resilient, friendly, cooperative, competitive, cheerful and persistent. Fourth, affective creativity development, which includes friendly, respectful, tolerant, caring, helpful, 
mutual cooperation, nationalism, cosmopolitan character, prioritizes public interests, is proud to use domestic language and products, dynamic, works hard, and has a work ethic [23].

Based on the above character, jihad learning is able to contribute to build certain characters. The privilege offered by jihad learning is that the character that is built is based on the faith of tauhid [23]. The tauhid-based character makes this character stronger (tsabat), istiqamah, and always takes sides and defends the truth based on the guidance of revelation. The characters that can be built through learning jihad include:

a. Character of charity with an awareness of responsibility to God.

Every practice in Islam is subject to responsibility to Allah. This is what determines the quality of a deed. With the awareness to take responsibility for every action, the boundaries between good and bad will become clearer. Jihad learning in the meaning of struggle and serious efforts can raise students' awareness to learn and do their best so that they can be responsible for their actions before Allah SWT.

Furthermore, Rasulullah said as narrated by Ibn Umar: "Everyone of you is a leader and is responsible for his charges: The Imam (ruler) of the people is a leader and is responsible for his subjects; a man is the leader of his family (household) and is responsible for his subjects; a woman is the leader of her husband's home and of his children and is responsible for them; and the slave of a man is a leader of his master's property and is responsible for it. Surely, everyone of you is a leader and responsible for his charges". (Narrated by Bukhari). In this history the demand for responsibility is also asked of each person for everything he had and what he did.

The learning of jihad theoretically and practically provides an example of the importance of focusing the goals of each deed to be oriented towards ukhrawi (heavenly) goals. The purpose of this ukhrawi is to improve the responsibility of students. It is not only limited on learning and charity with the aim of high grades, praise of teachers and parents, or to find work, which leads to the failure of character education.

b. Patient and courageous character

Patience is the main character that must be possessed in doing jihad, whether in a defensive or offensive context. Every effort made to charity and strive in the way of Allah will always require patience. Patience character is not easy to obtain unless through a rigorous training process. Umar bin Khattab asked the seniors from among the Bani Abbas: "With what are you fighting humans?" They replied: "With patience. We do not meet a community but we are patient with them as they are patient with us." Patience also means a character that is able to refrain from anxious nature and feelings of emotion, then refrain from verbal complaints and control the body from undirected actions. Patience is one of moral foundations in Islam. The foundation is patience that affects all aspects of human life [29]. Someone's patience can bring about the desired success, of course, with the permission of Allah.

Meanwhile, a brave character can also be instilled through jihad education. Ibn Qayyim mentioned that courage (syuja'ah) is a toughness and courage to face something scary, and courage is a deed that is born from good prejudice to Allah. Courage is one of the Islamic morals [23].

Internalization of brave character through jihad education can be done through historical materials of the struggle for Islamic $d a^{\prime} w a h$ either through oral, mental or strength. Every journey of da'wah taken by the sahabahs, tabi'in and tabi 'tabi'in is an example for students regarding the high patience and strong courage of Muslims.

c. Critical and patriotic character 
Jihad in a context of defensive and offensive trains a critical thinking to grow in students. Critical thinking is at the heart of the science civilization. It allows scientists to continue to innovate, invent from previous studies, through correction or even dismantle and offer originality that was never imagined before. It is no wonder that the leading universities in the world make critical thinking as one of the main expectations in the education process [30]. Critical thinking requires serious effort in the process of finding the truth. This is contained in the value of jihad as a form of strong action to uphold the truth and convey the truth to others without fear of accepting risks and threats.

Jihad learning also fosters a spirit of patriotism in the character of students. Patriotic values are instilled through the historical facts of Muslim jihad both during the classical period and during the Indonesian independence. The spirit of patriotism demands a person's willingness to sacrifice one's wealth and soul in the way of Allah. In the context of defensive jihad, students are trained to achieve goals through all the efforts permitted in Islam, even though at the expense of considerable energy and material. Meanwhile, in the context of offensive jihad, Islam provides a very noble reward for the martyrs' fi sabil Allah. In order to avoid the impact of radicalism on this issue, it is necessary to emphasize the aims and provisions of jihad as referred to in Islamic teachings.

\section{d. Professional character and prioritizing common interests}

Exemplary lessons learned from the topic of jihad are discipline, focus on the main goal, firm and asertive. These attitudes describe a person's professionalism. Professionalism is usually interpreted as a view to always think, have a stand, behave and work seriously, with discipline, honesty, and full dedication to achieve satisfying work results. Professionalism does not only depend on intellectual abilities, but also moral, social and cultural professionalism. The overall attitude of professionalism can be emulated through the learning of jihad, which contains the motivation to work hard, be diligent, assertive, discipline and be ready to take responsibility for all actions. An attitude of professionalism will be even more noble if it is accompanied by a high sense of sympathy, empathy and generosity. These attitudes are a major part of the character that prioritizes common interests. In the practice of jihad, a Muslim is required to sacrifice his property and life. These sacrifices provide examples of generosity and kindness. Generosity that emerges from empathy shows that social interests are more important than personal interests.

From the above discussion, it can be seen that the mujahid characters designed by Islam are tough and noble characters. This character can be developed in the student's personality as well as contributing to increasing intellectual, spiritual and social abilities.

\section{Conclusion}

Jihad as a fundamental teaching in Islam cannot be separated from the grand design of Islamic education. The main task of any party concerned with the issue of Islamic education is to keep the theme of jihad in educational institutions so that it is not considered a medium for planting radicalism and terrorism. The first thing to do is to emphasize the true meaning of jihad as referred to in the Al Quran and the hadith in a comprehensive manner. The second step is to re-explore the historical facts of jihad during the salaf generation and the heyday of classical Islam. Then to make these facts as the main material for the development of jihad learning materials. 
Through comprehensive and exemplary-oriented learning of jihad, this topic makes a major contribution in instilling a character to work with full responsibility in the spiritual aspects of students, patient and courageous character in the emotional aspects of students, critical character in intellectual aspects, patriotic character, professionalism and prioritizing social interests.

From this discussion, it can be seen that learning the topic of jihad is very effective in instilling noble characters and completing the internalization of values through other religious materials. Therefore, the discourse of eliminating and reducing the topic of jihad in Islamic religious subject is irrelevant to the current conditions of education which are oriented towards character education.

\section{References}

[1] R. W. Hefner, Making Modern Muslims, The Politics of Islamic Education in Southeast Asia. Univerity of Hawaii Press, 2009.

[2] S. S. Misra, "Islamic Terrorism in Indonesia," in ASIAN Affairs, 2003.

[3] Sulasman, "Peaceful Jihad dan Pendidikan Deradikalisasi Agama," Walisongo, vol. 23, no. 1, p. 152, 2015.

[4] M. Cholil, "Relevansi Pemikiran Tafsir Jihad M. Quraish Shihab," J. Stud. Keislam., vol. 1, no. 2, p. 539, 2015.

[5] C. Indonesia, "Kemenag Revisi Konten Khilafah dan Jihad di Buku Madrasah." 2019.

[6] A. Imron, "The Implementation of Jihad Concept in Education," in Proceedings of the 6th International Conference on Community Development (ICCD 2019), 2019, p. 349.

[7] M. Arifinsyah, Ryandi, "Pesantren Religious Paradigm: Aqeedah, Plurality, and Jihad," J. Soc. Media, vol. 3, no. 2, pp. 278-298, 2019.

[8] M. Ainin, Metodologi Penelitian Bahasa Arab. Malang: Hilal Pustaka, 2007.

[9] M. Zed, Metode Penelitian Kepustakaan. Jakarta: Yayasan Obor Indonesia, 2004.

[10] M. Q. Shihab, Wawasan Al-Quran: Tafsir Maudhu'i Pelbagai Persoalan Umat, VIII. Bandung, 1998.

[11] D. Irawan, "Kontroversi Makna dan Konsep Jihad dalam Al-Quran tentang Menciptakan Perdamaian," Religi, vol. 10, no. 1, pp. 67-68, 2014.

[12] Ramlan, “The Concept of Jihad In Islam," IOSR J. Humanit. Soc. Sci., vol. 21, no. 9, pp. 35-42, 2016.

[13] M. F. 'Abd Al-Baqi, Al-Mu'jam al-Mufahras li Alfazh al-Qur'an al-Karim. Kairo: Dar al-Rayyan li al-Turats.

[14] M. Chirzin, Jihad Menurut Sayid Qutub Dalam Tafsir Zhilal, 1st ed. Laweyan: Era Intermedia, 2001.

[15] M. H. Al-Taba'taba'i, Al-Mizan fi Tafsir al-Qur'an, Jilid XV. Beirut: Muassasah al'Alami li al-Matbuat, 1983.

[16] Bunyamin, Teknik Interpretasi Historis dalam Penafsiran al-Qur'an; Implementasi Terhadap Ayat-ayat Jihad. Program Pascasarjana UIN Alauddin Makassar, 2012.

[17] A. B. Ramdhun, Al-Jihad Sabiluna. Solo, 2002.

[18] A. Bazith, "Jihad dalam Perspektif Al-Quran," Tafsere, vol. 2, no. 1, pp. 67-93, 2014. 
[19] H. Aydin, "Jihad in Islam," GJAT, vol. 2, no. 2, pp. 7-15, 2012.

[20] I. Saputra, "Resolusi Jihad: Nasionalisme Kaum Santri Menuju Indonesia Merdeka," J. Islam Nusant., vol. 3, no. 1, pp. 205-237, 2019.

[21] Y. Qardhawi, Fiqih Jihad: Sebuah Karya Monumental Terlengkap Tentang Jihad Menurut Al-Quran dan Sunnah. Bandung, 2010.

[22] R. Triana, "Internalisasi Jihad dalam Pendidikan Karakter," Edukasi Islam. J. Pendidik. Islam, vol. 7, no. 1, pp. 101-129, 2018.

[23] R. Ibrahim, "Jihad dalam Literatur Pesantren Salaf," Teologia, vol. 23, no. 1, pp. 175-191, 2012.

[24] B. Bloom, "Taxonomy of Educational Objectives.” McKey New York, New York, 1956.

[25] A. H. A. bin M. bin H. Al-Mawardi, Ahkam al-Sulthaniyah. Beirut, 1960.

[26] A. bin S. A. A. ar-R. An-Nasa'i, Sunan an-Nasa'i. Khlmab: Maktab Al-Mathbu'at alIslamiyah.

[27] Z. Darajat, "Jihad Dinamis: Menelusuri Konsep dan Praktik Jihad dalam Sejarah Islam,” Ijtihad, J. Wacana Huk. Islam dan Kemanus., vol. 16, no. 1, pp. 1-25, 2016.

[28] Sukino, "Konsep Sabar dalam Al-Quran dan Kontekstualisasinya dalam Tujuan Hidup Manusia melalui Pendidikan,” Ruhama, vol. 1, no. 1, pp. 63-77, 2018.

[29] A. Sulaiman, "Berpikir Kritis: Mendorong Introduksi dan Reformulasi Konsep dalam Psikologi Islam,” Bul. Psikol. Islam, vol. 26, no. 2, pp. 86-96, 2018. 